\title{
Wobbe Index Determination of Cattle Dung Biogas
}

\author{
Yaru, S. S. ${ }^{1} \quad$ Adegun, I. K. ${ }^{2} \quad$ Akintunde, M. A. ${ }^{1}$ \\ 1. Department of Mechanical Engineering \\ School of Engineering and Engineering Technology, The Federal University of Technology, Akure, Nigeria \\ 2. Department of Mechanical Engineering \\ Faculty of Engineering and Technology, University of Ilorin, Ilorin, Nigeria
}

\begin{abstract}
This paper is aimed at determining the Wobbe Index (W I) of cattle dung biogas which is the amount of energy delivered to a burner through an injector or orifice especially during combustion. The biogas was produced by anaerobic digestion of cattle dung in a batch digester within two weeks. Pressure and temperature of the digester were monitored at 12 noon daily. The analysis of the combustible biogas using thermal conductivity detector (TCD) revealed $\mathrm{CH}_{4}$ at $0.562, \mathrm{CO}_{2} 0.395, \mathrm{H}_{2} \mathrm{~S} 0.018, \mathrm{CO} 0.019$ and 0.005 moles for $\mathrm{NH}_{3}$ by volume. Its calorific value (C V) using gas calorimeter Junkers was $19.5 \mathrm{MJ} / \mathrm{m}^{3}$. The cumulative specific volume of the biogas rose from zero through day 1 to $0.622732 \mathrm{~m}^{3} / \mathrm{kg}$ on the sixth day before recording daily marginal increments with the rest of the days of incubation. The relative density of the biogas also had a sharp rise on the second day at 5.039208 before dropping to 2.51126 and then gradually decreased daily to the end of digestion. The Wobbe Index equally rose from zero on the first day through to $12.08434 \mathrm{MJ} / \mathrm{m}^{3}, 14.07783 \mathrm{MJ} / \mathrm{m}^{3}$ and $15.87665 \mathrm{MJ} / \mathrm{m}^{3}$ on days $2,3,4$ and 5 respectively after which it had logarithmic increments. The volatile solids destroyed also recorded logarithmic rise while the bacterial growth rate followed the zigzag pattern as those of internal energy and enthalpy. It is therefore concluded that parameters like the cumulative specific volume and Wobbe Index increased throughout the incubation period while those that are directly temperature dependent varied with the temperature of the digester.
\end{abstract}

Keywords: Wobbe Index, calorifc value, cattle dung, biogas, batch digester, specific volume, relative density, internal energy, enthalpy

\subsection{Introduction}

The energy crises as a result of unacceptable upsurge in the prices of the fossil fuels in the 1970s compelled the developed nations to intensify the research in to alternative energy drives. In addition, the realization in the 1980s that products of combustion of these fuels which is principally carbon dioxide having the highest percentage, being underlying compound responsible for the global warming phenomenon, really increased the research momentum of these countries in to renewable energy sources. Furthermore, the observation that the fossil fuels sources are being depleted without corresponding refurnishing made it absolutely necessary, this time around for both the developed and the developing nations to radially launch researches in to alternative and renewable energy sources. Renewable energy sources are many and include: Hydropower, solar, wind, ocean, geothermal and wastes among others. These renewable energy resources except for the wastes do not degrade in the process of usage but are capital intensive and some like hydropower are affected by seasonal changes and are also location specific. The wastes on the other hand are not capital intensive as such. They can however be either synthetic or biological in nature.

The synthetic wastes once attained this status are not biodegradable and as such require reasonable thermal energy in order to degrade. Examples of these wastes are used tyres, polythenes, plastics, and even charcoal. They now undergo processes like pyrolysis, gasification and so on to release energy in the form of gaseous fuels, liquid fuels and chars. For instance, Fernandez, et al., (2009) carried out pyrolysis of waste granulated tyres and tyre reinforcement fibres in a thermobalance horizontal oven at $550{ }^{\circ} \mathrm{C}$ and $900{ }^{\circ} \mathrm{C}$ to obtain $50-57 \%$ by weight on dry basis tar, 25-35\% gases mainly butane and iso-butane while the rest was char. Quek and Balasubramanian (2013) reported that the pyrolysis of a whole tyre could be done at a temperature as high as $950^{\circ} \mathrm{C}$ at $101325 \mathrm{~Pa}$ to produce $24 \%$ oil by weight. The pyrolysis of $300 \mathrm{~g}$ of shredded tyre scrap on a static batch reactor yielded solid (char), liquid (water and oils) and gas (light hydrocarbons, hydrogen, carbon monoxide and carbon dioxide) at a temperature range between 400 and $700^{\circ} \mathrm{C}$ (Berrueco, et al., 2005).

Biological wastes on the other hand are biodegradable through enzymatic reactions especially in an anaerobic environment. This gives rise to biogas which is a mixture of almost naturally occurring gases. The principal components of biogas are methane $\left(\mathrm{CH}_{4}\right)$ at $50-60 \%$ and carbon dioxide $\left(\mathrm{CO}_{2}\right)$ with $30-40 \%$ by volume with traces of hydrogen sulphide $\left(\mathrm{H}_{2} \mathrm{~S}\right)$, hydrogen $\left(\mathrm{H}_{2}\right)$, oxygen $\left(\mathrm{O}_{2}\right)$, nitrogen $\left(\mathrm{N}_{2}\right)$ and water vapour. For example, Ezekoye and Ezekoye (2009) reported that raw biogas contains about 55-65\% methane, 30-45\% carbon dioxide, traces of hydrogen and fractions of water vapour.

For a combustible biogas, the heating values vary like any other gaseous fuel depending on its source. The heating value determination is done in the form of calorific value and Wobbe index. It is a measure of energy 
delivered through an injector to a burner. It shows the compatibility between the natural gas supplied and the burner (GQHWG, 2004). A lot of work has been reported on the calorific value of biogas but little was done on Wobbe index for biogas. For instance, Raja, et al., (2012) conducted a variable calorific value tests on biogas and they showed that biogas with $56 \%$ methane had calorific value of $20 \mathrm{MJ} / \mathrm{m}^{3}, 62 \%$ with $22.1 \mathrm{MJ} / \mathrm{m}^{3}$ and $70 \%$ methane had $25 \mathrm{MJ} / \mathrm{m}^{3}$. Beddoes, et al., (2007) reported that the heating value of biogas is $212 \mathrm{MJ} / \mathrm{m}^{3}$. Adegun and Yaru (2013) generated biogas from cattle dung and its analysis using thermal conductivity detector showed $\mathrm{CH}_{4}$ with $56.20 \%, \mathrm{CO}_{2}$ with $39.50 \%, \mathrm{H}_{2} \mathrm{~S}, 1.08 \%, \mathrm{CO} 1.90 \%$ and ammonia $\left(\mathrm{NH}_{3}\right) 0.50 \%$. They also reported that the calorific value of the biogas was $19.50 \mathrm{MJ} / \mathrm{m}^{3}$. Wobbe Index of biogas with $60 \% \mathrm{CH}_{4}, 38 \% \mathrm{CO}_{2}$ and $2 \%$ others had $19.5 \mathrm{MJ} / \mathrm{m}^{3}$ and that of natural gas to be $39.9 \mathrm{MJ} / \mathrm{m}^{3}$ (DTI, 2012). dung only.

The objective of this paper therefore is to determine the Wobbes index of the biogas generated from cattle

\subsection{Theory of biogas production}

Biogas is a product of metabolism of methane-bacteria and is created when bacterial decompose a mass of organic material anaerobically. The energy needed for the activities of bacterial involves reduction and oxidation process (electron donor and acceptor). This may be endogenous (from within the cell) or exogenous (from outside the cell). The use of internal electron is known as fermentative metabolism (Tchobanoglous, et al., 2003). The bacteria can only work and produce the biogas if the substrate is sufficiently bloated with water at least 50\% (Vindin, et al., 2008). It is produced from a three-phase process; namely hydrolysis (which converts polymer to monomer) by hydrolytic bacterial (Iyagba, et al, 2009), acid-forming (acidogenesis) and methane-forming (methanogenesis). In the hydrolysis phase extra cellular enzymes secreted breakdown the complex organic substances into simple soluble molecules. The acidogenesis stage involves the breakdown of the simple molecules to volatile fatty acids (VFAs) such as propionic and butyric acids, carbon dioxide, ammonia and hydrogen while the methanogenesis phase converts the VFAs to methane, carbon dioxide, nitrogen, and hydrogen sulphide. Fusarium fungai and staphylococcus bacteria are involved in the anaerobic digestion process (Itodo, 2007).

Enzymatic activities of micro-organisms responsible for the bioconversion of substrates to biogas are affected by temperature in ranges. Psychrophilic temperature range being below $20^{\circ} \mathrm{C}$, mesophillic temperature range, $20-40^{\circ} \mathrm{C}$ and the thermophilic temperature range is $40-65^{\circ} \mathrm{C}$. Thermophilic temperature range allows for shorter retention time and because of the high temperature of this phase there is little or no room for pathogens to thrive. The mesophilic range is the most common especially in the tropics where ambient temperature of $40^{\circ} \mathrm{C}$ is naturally attainable.

\subsection{Generation of biogas}

Cattle dung was collected from a local cattle ranch in Ilorin, Nigeria. This was crushed by beating it to pulp in synthetic fibres sacks. $8 \mathrm{~kg}$ of the cattle dung was mixed with equal volume of water charged to a digester up to $75 \%$ of its volume. The digester was made of $2 \mathrm{~mm}$ thick mild steel. The mixture was stirred thoroughly to make uniform slurry before being closed tightly and subjected to anaerobic incubation in the laboratory at the Kwara State Polytechnic, Ilorin, Nigeria. The gas was daily tested for combustion and it burnt with a blue flame on the $13^{\text {th }}$ day of incubation. The raw biogas was collected in a cylinder and was analyzed using thermal conductivity detector.

\subsection{Calculations for biogas parameters}

The following assumptions were made in the course of the design calculations for the determination of the biogas parameters: the calorific value of the biogas is constant throughout the incubation period; the density of air is constant at all temperatures referred to herein; the temperature of the biogas in the digester is the same as that of substrate during the incubation period; equations (13) and (14) of plug flow digesters reported by Gebremedhin and Inglis (2007) were adaptable to batch digesters.

The additional equations employed in the determination of the biogas parameters were obtained from Rajput, (2011), Rajput, (2003), Rogers and Mayhew (1988), www.hobre.com

$$
n=\frac{m}{M}
$$

The mass fraction, $\mathrm{m}_{\mathrm{a}}$ is as given in equation (2)

$$
m_{a}=\frac{m_{i}}{m}
$$

The specific biogas constant $(\mathrm{R})$ was estimated as given in equation (3) 


$$
R=\sum_{i=1}^{n} R_{i}=\frac{R_{o}}{m} \sum_{i=1}^{n} \frac{m_{i}}{M_{i}}
$$

Specific heats at constant pressure, $c_{\mathrm{p}}$, and at constant volume, $c_{\mathrm{v}}$ of the biogas are given in equations (4) and (5) respectively.

$$
\begin{gathered}
c_{p}=\sum_{i=1}^{n} \frac{m_{i}}{m}\left(c_{p}\right)_{i} \\
c_{v}=\sum_{i=1}^{n} \frac{m_{i}}{m}\left(c_{v}\right)_{i}
\end{gathered}
$$

For diatomic gases

$$
\left(c_{v}\right)_{i}=\frac{5}{2} R_{i}
$$

and

$$
\left(c_{p}\right)_{i}=\frac{7}{2} R_{i}
$$

For poly atomic gases

$$
\left(c_{v}\right)_{i}=3 R_{i}
$$

and

$$
\left(c_{p}\right)_{i}=4 R_{i}
$$

Determination of specific volume and relative density of the biogas was done using equations (10) and (11)

$$
\begin{aligned}
& v=\frac{R_{T} T}{P_{e}} \\
& R D_{\text {biogas }}=\frac{\rho_{\text {biogas }}}{\left(\rho_{\text {air }}\right)^{0.5}} \\
& W I=\frac{H}{\left(R D_{\text {biogas }}\right)^{0.5}}=H v^{0.5}\left(\rho_{\text {air }}\right)^{0.25} \\
& \mu_{m}=0.013 T-0.129 \\
& V_{d}=13.7 \log _{e}\left(S R T_{\text {dest }}\right)+18.9
\end{aligned}
$$

The specific internal energy and specific enthalpy of the biogas were done using equations (15) and (16)

$$
\begin{gathered}
u=c_{v} T \\
h=c_{p} T
\end{gathered}
$$

Where:

$\mathrm{R}_{\mathrm{o}}$ is the Universal gas constant $(\mathrm{kJ} / \mathrm{kgK})$;

$R_{i}$ is the specific gas constant of a component gas in the biogas mixture $(\mathrm{kJ} / \mathrm{kgK}) ; \mathrm{m}_{\mathrm{i}}$ is the mass of a component gas in the mixture $(\mathrm{kg}) ;\left(\mathrm{c}_{\mathrm{v}}\right)_{\mathrm{i}}$ and $\left(\mathrm{c}_{\mathrm{p}}\right)_{\mathrm{i}}$ are respectively the specific heat at constant volume and at constant pressure for component gas of the biogas mixture $(\mathrm{kJ} / \mathrm{kgK}) ; \mathrm{u}$ and $\mathrm{h}$ are specific internal energy and specific enthalpy of the biogas $(\mathrm{kJ} / \mathrm{kgK}) ; \mathrm{T}$ is the inside absolute temperature of the digester; $\rho_{\text {biogas }}$ and $\rho_{\text {air }}$ are densities of biogas and air $\left(\mathrm{kg} / \mathrm{m}^{3}\right)$ respectively; $\mathrm{RD}_{\text {biogas }}$ is the relative density of the biogas; $\mu_{\mathrm{m}}$ is bacterial growth rate per day; $\mathrm{V}_{\mathrm{d}}$ is volatile solids destroyed; $H$ is the calorific value of biogas; and $v$ is specific volume of biogas; and $\mathrm{SRT}_{\text {dest }}$ is the solids retention time which is also the days of incubation.

\subsection{Gas Chromatography (GC)}

The chromatography system is composed of the chromatograph and a recorder for plotting chromatographs. The experiment was conducted using thermal conductivity detector (TCD) at Multi- Environmental Management Consultants Ltd, Igbe, Ikorodu, Lagos, Nigeria. 


\subsection{Gas Calorific value determination}

Combustion of a gas in an open flame calorimetric method with open flame for the determination of the calorific values of gaseous samples was employed using gas calorimeter Junkers. The basic principle was based on the specific amount of gas that was metered and completely burnt. By a heat exchanger, the heat of combustion released by the burner was transferred to a metered heat absorbing air. As a result, the temperature of the fluid increased. The temperature increase was a measure of the calorific value. The calibration of the equipment was carried out by using gases of known calorific value.

\subsection{Results and Discussions}

The results obtained by using equations (1) to (9) are as shown in Table 1

Table 1: Constituents of the cattle dung biogas and their thermo-physical properties

\begin{tabular}{llllllll}
\hline Constituent & $\begin{array}{l}\text { Mole } \\
\left(\mathrm{n}_{\mathrm{i}}\right)\end{array}$ & $\begin{array}{l}\text { Molar } \\
\text { mass } \\
(\mathrm{kg})\end{array}$ & $\begin{array}{l}\text { Mass in the } \\
\text { mixture }(\mathrm{kg}) \\
\left(\mathrm{m}_{\mathrm{i}}=\mathrm{n}_{\mathrm{i}} \mathrm{M}_{\mathrm{i}}\right)\end{array}$ & $\begin{array}{l}\text { Mass fraction } \\
\left(\mathrm{m}_{\mathrm{j}} / \mathrm{m}\right)\end{array}$ & $\begin{array}{l}\text { Specific gas } \\
\text { constant }\left(\mathrm{R}_{\mathrm{i}}\right) \\
(\mathrm{kJ} / \mathrm{kgK})\end{array}$ & $\begin{array}{l}\text { Constant volume } \\
\text { specific heat }\left(\mathrm{c}_{\mathrm{v}}\right) \mathrm{i}\end{array}$ & $\begin{array}{l}\text { Constant pressure specific } \\
(\mathrm{kJ} / \mathrm{kgK})\end{array}$ \\
\hline $\mathrm{CH}_{4}$ & 0.562 & 16 & 8.992 & 0.3257853 & .1692862 & .5078585 & .6771447 \\
$\mathrm{CO}_{2}$ & 0.395 & 44 & 17.38 & 0.6296873 & .1189823 & .3569469 & .4759292 \\
$\mathrm{H}_{2} \mathrm{~S}$ & 0.018 & 34 & .612 & $2.2173 \mathrm{E}-02$ & $5.421977 \mathrm{E}-03$ & $1.626593 \mathrm{E}-02$ & $2.168791 \mathrm{E}-02$ \\
$\mathrm{CO}$ & 0.019 & 28 & .532 & $1.9275 \mathrm{E}-02$ & $5.723198 \mathrm{E}-03$ & .014308 & .0200312 \\
$\mathrm{NH}_{3}$ & 0.005 & 17 & .085 & $3.0796 \mathrm{E}-03$ & $1.506105 \mathrm{E}-03$ & $4.518315 \mathrm{E}-03$ & $6.02442 \mathrm{E}-03$ \\
& & & & & & & \\
Total & & & 27.601 & & 0.3009197 & 0.8998976 & 1.200817 \\
\hline
\end{tabular}

The thermo-physical properties of the biogas are as shown in Table 1. The biogas constituents are in column 1 , the moles of the constituents in $2^{\text {nd }}$ column and their respective molar masses are in column 3 . The mass of every constituent in the mixture is located in column 4 , mass fraction and the specific gas constant in columns 5 and 6 respectively. The specific heats at constant volume and pressure of the component gases are in columns 7 and 8 .

The six rows in Table 1 show gas constituents with $\mathrm{CH}_{4}$, being first, $\mathrm{CO}_{2}$ is second, $\mathrm{H}_{2} \mathrm{~S}$ being third, $\mathrm{CO}$ fourth and $\mathrm{NH}_{3}$ fifth. The values of the parameters except for the ratios of the specific heats are added as shown in row 6. Each constituent gas in the biogas mixture had total mole with $\mathrm{CH}_{4}$ as $0.562, \mathrm{CO}_{2} 0.395, \mathrm{H}_{2} \mathrm{~S} 0.018, \mathrm{CO}$ 0.019 and 0.005 for $\mathrm{NH}_{3}$ thus bringing the total mole of the biogas to 0.999 in column 2 . The molar masses of the constituent gases are in the order of $16 \mathrm{~kg}, 44 \mathrm{~kg}, 34 \mathrm{~kg}, 28 \mathrm{~kg}$ and $17 \mathrm{~kg}$. The sum of the respective properties of constituents in each column is shown in the $6^{\text {th }}$ row for columns $2,4,6,7$ and 8 . Constituents' total mass in the biogas mixture was $27.601 \mathrm{~kg}$, biogas constant $\mathrm{R}$ was $0.3009197 \mathrm{~kJ} / \mathrm{kgK}$, specific heat at constant volume $\left(\mathrm{C}_{\mathrm{v}}\right)$ was $0.8998976 \mathrm{~kJ} / \mathrm{kgK}$ and specific heat at constant pressure $\left(\mathrm{C}_{\mathrm{p}}\right)$ was $1.200817 \mathrm{~kJ} / \mathrm{kgK}$. The calorific value of the biogas was $19.50 \mathrm{MJ} / \mathrm{m}^{3}$.

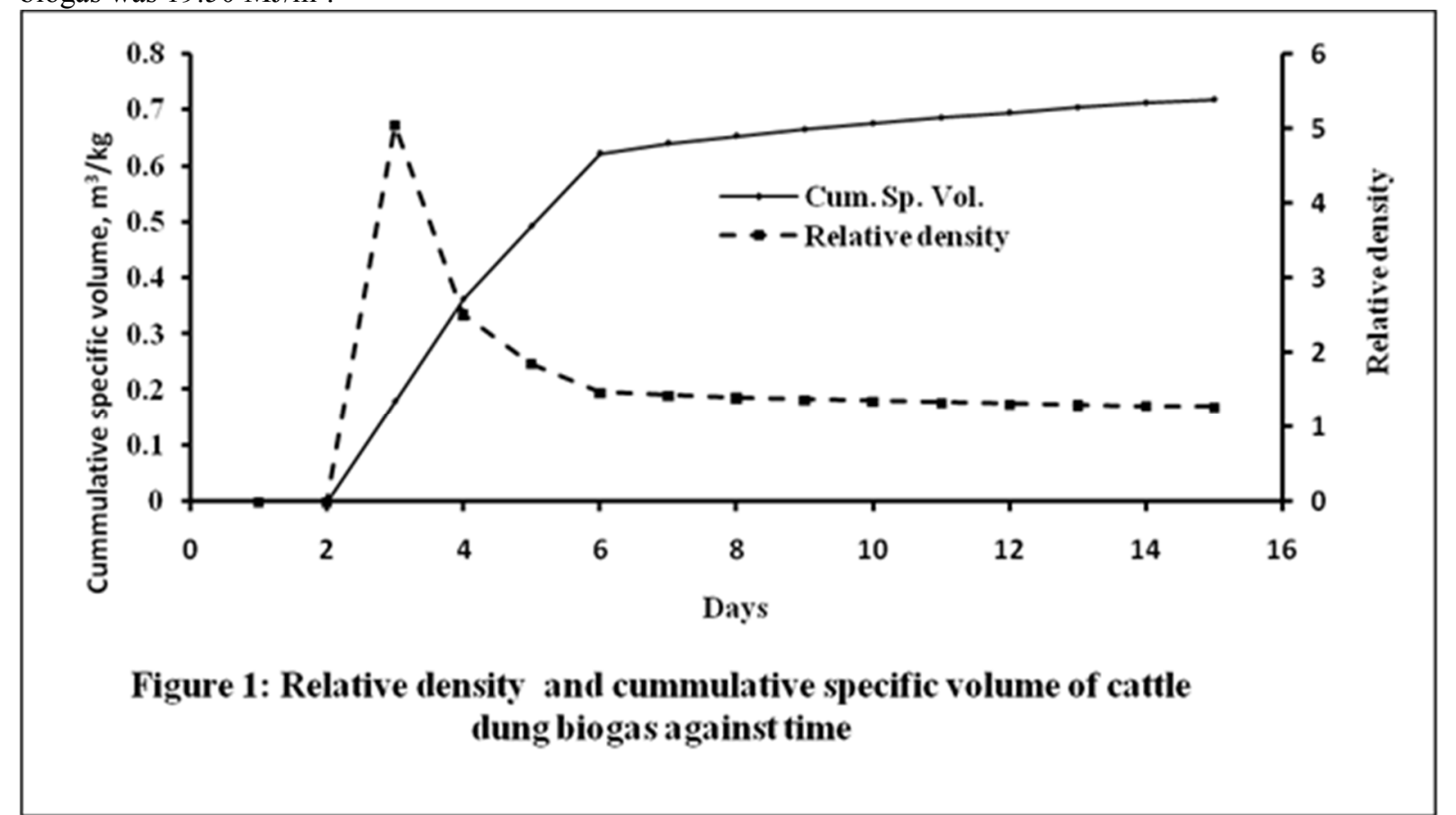

Figure 1 shows the variation of relative density and the cummulative specific volume of the cattle dung biogas with timefor the two weeks of the incubation period. The relative density of the biogas rose sharply on the second day of incubation to 5.039208 before dropping sharply to 2.511261 on the third day. Thereafter it assumed 
a relatively slower fall or gentle downward turn through 1.850403 and 1.465913 till day 6 with 1.424475 . It marginally decreased till the end of incubation with a value of 1.270801 . The sharp rise of the relative density in the second day was as a result of air eclosed in the digester during charging which reacted with the substrate. This gave rise to production of carbon dioxide. As the carbon dioxide was used up as anaerobic digestion progressed there was slower production of the other components like methane of the biogas.

The cummulative specific volume of the biogas also rose steadily on day 2 from zero to $0.622732 \mathrm{~m}^{3} / \mathrm{kg}$ on fifth day of incubation. After this period there was marginal increament of its specific volume, hence the graph assumed logarithmic behaviour to the end of incubation with $0.718343 \mathrm{~m}^{3} / \mathrm{kg}$ occuring on the last day.

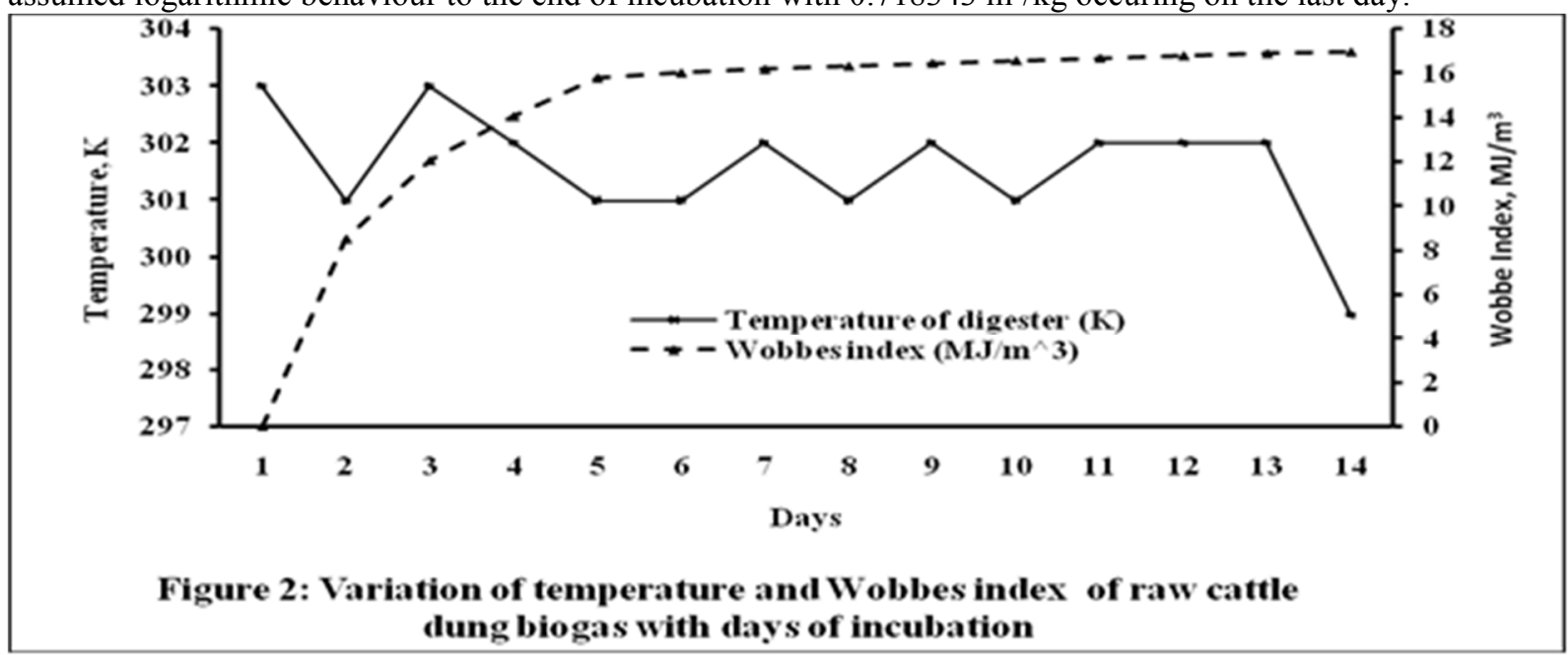

In Figure 2, the temperature plot had a zigzag behaviour because the digester was placed in an uncontrolled environment and therefore the temperature varied with the environmental conditions, hence its hapzard nature. On the other hand the Wobbe Index had a sharp rise from day 1 at zero to day 2 with 8.530758 $\mathrm{MJ} / \mathrm{m}^{3}$ thus indicating a high value, this is due to the reaction between the substrate and the air in the digester. The plot assumed a logarithmic shape from day 2 with $12.08434 \mathrm{MJ} / \mathrm{m}^{3}$ through today 5 with a value of 15.81665 $\mathrm{MJ} / \mathrm{m}^{3}$ and thereafter Wobbe Index recorded marginal increament as the anaerobic digestion progressed with $16.98752 \mathrm{MJ} / \mathrm{m}^{3}$ on the last day.

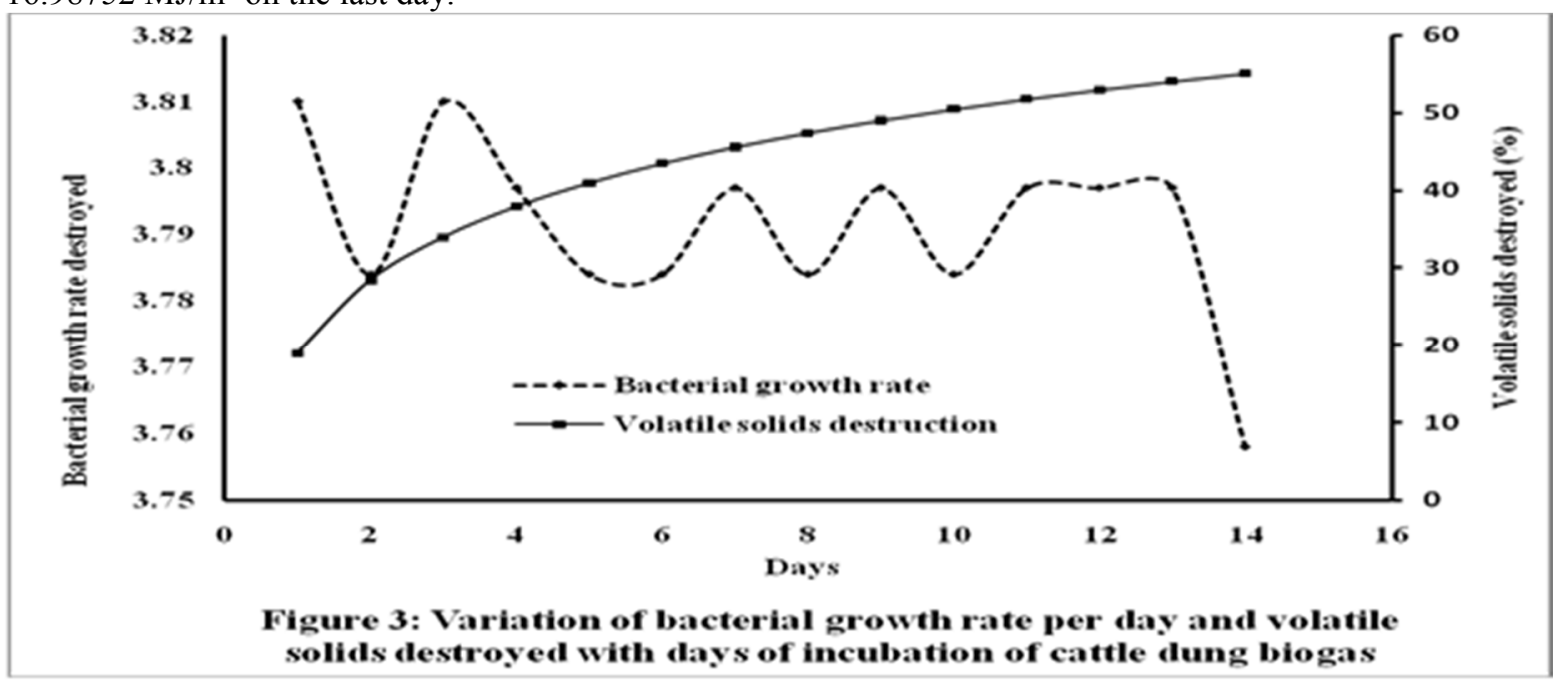

Figure 3 shows the plots of bacterial growth rate and voaltile solids destroyed against the the days of incubation. The daily bacterial growth rate had a zigzag behaviour because it was temperature dependent and so it varied with temperature of the digester. This was about 3.81 on the first day but dropped to almost 3.78 on the second to rsie again on the third day. The whole process went on that way till the last day when the growth rate was about 3.76 .

The volatile solids destroyed increased from almost $18.9 \%$ on the second day, assumed a logarithmic shape to $40.9493 \%$ on the fifth day and after then marginally increased throughout the rest incubation period thus indicating that the process of destruction of the volatile solids to produce biogas was slow but sure especially at the prevailing temperature at which the incubation took place. 


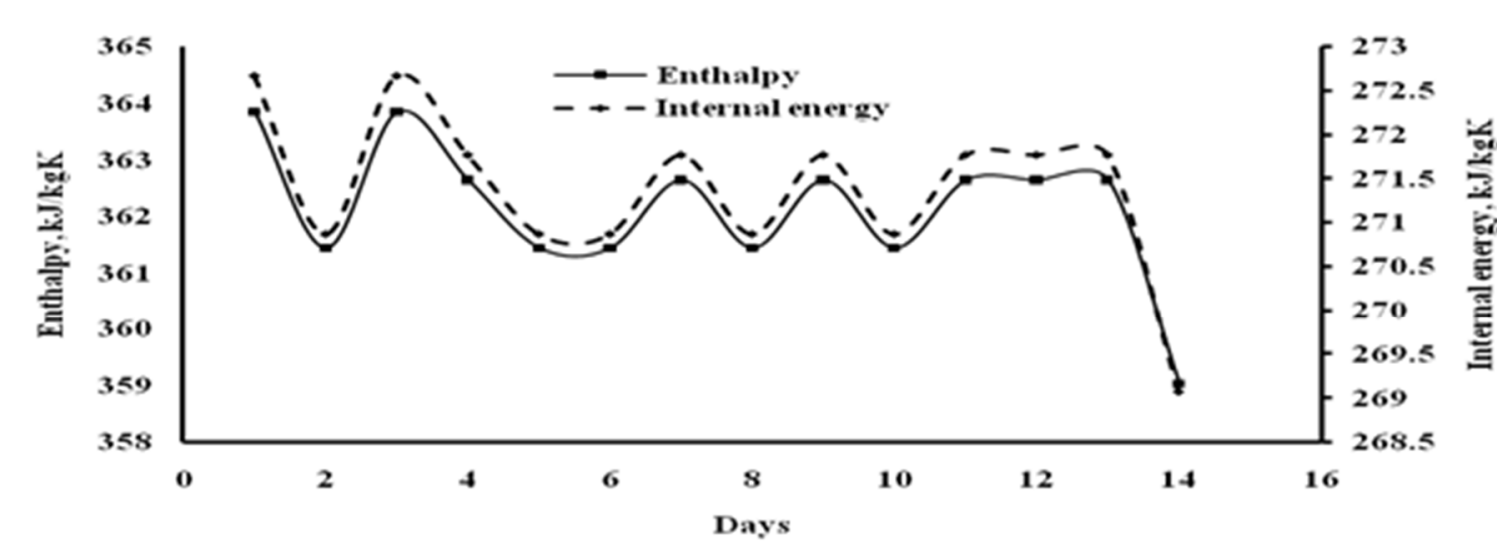

Figure 4: Internal energyand enthalpy of cattle dung biogas versus days of incubation

In Figure 4, the the plots of enthalpy and internal energy also recorded zigzag behaviours because they were dependent on the digester temperature which invarably interacted with the ambient temperature. As the ambient temperature rose, the digester temperature, the enthapy and the internal energy rose and they dropped with the fall in the ambient temperature. The enthalpy plots however had higher values with the highest being almost $364 \mathrm{~kJ} / \mathrm{kgK}$ and the lowest $359 \mathrm{~kJ} / \mathrm{kgK}$ than that of the internal energy of the biogas as it had the highest value of about $273 \mathrm{~kJ} / \mathrm{kgK}$ and the lowest $269 \mathrm{~kJ} / \mathrm{kgK}$. This is reasonable as the internal energy is a component part of enthalpy of the biogas.

\subsection{Conclusion}

The analysis of biogas generated from the anaerobic digestion of cattle dung using the GC/TCD showed its constituents as $\mathrm{CH}_{4}, \mathrm{CO}_{2}, \mathrm{H}_{2} \mathrm{~S}, \mathrm{CO}$ and $\mathrm{NH}_{3}$ with the respective moles as $0.562,0.395,0.018,0.019$ and 0.005 . The total mass in the biogas mixture was $27.601 \mathrm{~kg}$, biogas constant $\mathrm{R}$ was $0.3009197 \mathrm{~kJ} / \mathrm{kgK}$, specific heat at constant volume $\left(\mathrm{C}_{\mathrm{v}}\right)$ was $0.8998976 \mathrm{~kJ} / \mathrm{kgK}$ and specific heat at constant pressure $\left(\mathrm{C}_{\mathrm{p}}\right)$ was $1.200817 \mathrm{~kJ} / \mathrm{kgK}$. The relative density of the biogas rose sharply to about 4.28 before dropping to 2.14 to assume a slower and marginal downward turn. The cummulative specific volume of the biogas also rose steadily from zero to about $0.64 \mathrm{~m}^{3} / \mathrm{kg}$ before its logarithmic marginal increament to the end of incubation. The Wobbes index and volatile solids destroyed increased from $8.530758 \mathrm{MJ} / \mathrm{m}^{3}$ and $20 \%$ respectively and assumed logarithmic shapes followed with marginal increment till the day of incubation. The bacterial growth rate per day, the enthalpy and the internal energy of the varied with the digeter temperatures.

\section{References}

Adegun, I. K. and Yaru, S. S (2013), Cattle Dung Biogas as a Renewable Energy Source for Rural Laboratories, Journal of Sustainable Technology, Vol. 4, No 1, pp 1-8

Beddoes, J. C., Bracmort, K. S., Burns, R. T. and Lazarus, W. F (2007), An Analysis of Energy

Production Costs from Anaerobic Digestion Systems on U. S. Livestock Production Facilities, National Resources Conservation Service, United States Department of Agriculture, Technical Note, No. 1

Berrueco, C., Esperanza, E., Mastral, F. J., Ceamanos, J. and Garcia - Bacaica (2005), Pyrolysis of Waste Tyres in an Atmospheric Statuc-bed Batch Reactor: Analysis of the Gases Obtained, Journal of Analytical and Applied Pyrolysis, Science Direct, Vol. 74, pp 245-253. Available online from www.sciencedirect.com

DTI (2012), Danish Technological Institute Report on Biogas and bio-syngas upgrading, Laura Dailon Allegue and Jorgen Hinge Kongsvang Alle 29, DK-800, Aarhus C

Ezekoye, V. A. and Ezekoye B. A. (2009), Characterization and Storage of Biogas Produced Anaerobic Digestion of Cow Dung Spent Grains/Cow Dung and Cassava Peels/Rice Husk, The Pacific Journal of Science and Technology, Vol.10, No. 2, pp 898-904. Available online from http://www.akamaiuniversity.us/JPST.htm

Fernandez, M. A., Diez, A., Alvarez, R. and Barrocanal, C. (2009), Pyrolysis of Tyre Wastes , $1^{\text {st }}$ Spanish National Conference on Advances in Material Recycling and Eco-Energy, Madrid, SO 1-2

GQHWG (2004), Gas Quality Harmonization Working Group, Energy Charter Secretariat, Occasional Paper (2), LNG and Natural Gas Quality Standard, Boulevard de la Woluwe, 56, B-1200, Brussels. Available from: www.encharter.org

Gebremedhin and Inglis (2007), Validation of a Biogas Production Model and Determination of Thermal Energy 
from Plug- Flow Anaerobic Digesters, Transactions of the American Society of Agricultural and Biological Engineers, Vol. 5, No. 3, pp 975-979

Hobre Instrument, General Information, Wobbe Index and Calorimeters, Available from www.hobre.com Iyagba, E. T., Mangibo, I. A. and Mohammad, Y. S. (2009), The Study of Cow Dung as Co-substrate with Rice Husk in Biogas Production, Scientific Research and Essay, Vol. 4, No. 9, pp 861-866

Itodo, I.N. (2007), Agricultural Energy Technology, Aboki Publishers, Makurdi.

Quek, A. and Balasubramanian, R. (2013), Liquefaction of Waste Tyres by Pyrolysis for Oil and Chemicals - A review, Journal of Analytical and Applied Pyrolysis, Vol. 101, pp 1-16

Rajput, R. K. (2011), A Textbook of Engineering Thermodynamics, $4^{\text {th }}$ Edition, Laxmi Publishers Ltd, New Delhi Rajput, R. K. (2003), Thermal Engineering, Laxmi Publications Ltd, New Delhi.

Raja, A. S. and Lee, R. L. C. (2012), Biomethanation of Water Hyacinth Using Additives under Forced Mixing in a Bioreactor, Int., J. Chem. Res., 2012vi02i4 (15-24).

Roger, G. F. C. and Mayhew, Y. R. (1988), Engineering Thermodynamics, ELBS/Longman, Hong Kong

Tchobanoglous, G., Burton, F. L. and Stensel, H. D. (2003), Waste Water Engineering (Treatment snd Resource), Metcalf and Eddy, Tata Mcgraw-Hill publishers, New Delhi.

Vindin, P., Mursec, B., Rozmac, C., Janzekovic, M. and Cus, F. (2008), Biogas Production with the

use of Mini Digester, Journal of Achievements in Materials and Manufacturing Engineering, Vol. 28, No. 1, pp. 99-102. 